\title{
Karierni cikel in začetna motivacija slovenskih srednješolskih učiteljev
}

\author{
Tina Štemberger \\ Univerza na Primorskem \\ tina.stemberger@upr.si
}

\begin{abstract}
Prispevek se usmerja v karierni cikel in začetno motivacijo srednješolskih učiteljev v Sloveniji in temelji na modelu kariernega cikla učiteljev. Cilj študije je bil ugotoviti, ali obstajajo razlike $v$ kariernih stopnjah in začetni motivaciji učiteljev glede na vrsto zaključenega začetnega izobraževanja učiteljev in dolžino delovne dobe $v$ šolstvu ter ali obstaja povezanost med doživljanjem kariernih stopenj in začetno motivacijo. V študijo je bilo vključenih 94 srednješolskih učiteljev, ki so izpolnili slovensko različico lestvice karierne izbire in lestvice kariernega razvoja. Rezultati kažejo, da so ženske bolj notranje motivirane za izbiro poklica, moški pa izkazujejo večjo negotovost v stroki. Višnjo stopnjo notranje motiviranosti je zaznati tudi pri učiteljih, ki so zaključili sočasne programe začetnega izobraževanja.
\end{abstract}

Ključne besede: učitelj, karierne stopnje, začetna motivacija

\section{Uvod}

Organizacija OECD (OECD 2009) profesionalni razvoj (PR) učiteljev opredeljuje kot »dejavnosti, s katerimi se razvijajo posameznikove spretnosti, znanje, profesionalno znanje in tudi učitelj kot osebnost«. Učinkovit profesionalni razvoj vključuje usposabljanje, prakso in kakovostne povratne informacije, za kar je potrebno zagotoviti dovolj časa in ustrezno podporo (OECD 2005). Darling-Hammondova, Hylerjeva in Gardnerjeva $(2017,1)$ profesionalni razvoj opredeljujejo kot »strukturirano strokovno učenje, ki rezultira v spremembi znanja in praks učiteljev ter posledično vpliva na izboljšanje učnih izidov učencev«. Profesionalno učenje lahko razumemo tudi kot produkt zunanjih in notranjih dejavnikov, ki učitelje opolnomočijo in skozi katere ti spreminjajo lastno vzgojno-izobraževalno prakso na način, s katerim podpirajo učenje učencev. Poleg vhodno-izhodno usmerjenih opredelitev profesionalnega razvoja nekatere definicije koncepta profesionalnega razvoja (Evans 2002) temeljijo na izhodišču, da je učiteljev profesionalni razvoj proces, ki temelji na učiteljevem raziskovanju lastne prakse in konstrukciji lastnih teorij poučevanja (Keiny 1994), ali da je profesionalni razvoj mogoče opredeliti kot proces učenja učiteljev, v katerem učitelji razvijajo svoja prepričanja, ideje in 
vzgojno-izobraževalno prakso, pri čemer upoštevajo tudi svoja čustva (Bell in Gilbert 1994). Evansova (2002) poudarja, da je profesionalni razvoj učiteljev proces, ki se lahko razume kot notranji proces ali kot od zunaj spodbujen proces, ki je usmerjen $v$ učitelje, kar lahko izboljša njihove kompetence. Valenčič Zuljanova (2001) je oblikovala definicijo, za katero se zdi, da združuje večino elementov, ki so jih navedli tudi drugi avtorji. Učiteljev profesionalni razvoj opredeljuje kot proces pomembnega in vseživljenjskega izkustvenega učenja, $v$ katerem učitelj konstruira svoje koncepte in spreminja svojo prakso. Proces vključuje učiteljevo osebno, strokovno in socialno dimenzijo ter upošteva njegov razvoj v smeri kritičnega, neodvisnega in odgovornega strokovnjaka.

Za učitelje je ključnega pomena, da se vključijo v nadaljnje profesionalno usposabljanje, saj zaradi hitrega razvoja družbe in njenih potreb vedno znova potrebujejo nove, drugačne kompetence, ki jih morda v procesu začetnega izobraževanja za poklic niso pridobili (Brookfield 2005; Goodson 2003; Ministrstvo za izobraževanje, znanost in šport 2001; Persson 2006; Ministrstvo za šolstvo in šport 2011). Zanimiv je tudi poudarek Villegas-Reimersove (2003), ki navaja, da je razvoj učiteljev dolgoročni proces, v katerem učitelji ne pridobijo le specifičnega znanja, pač pa pridobijo in razvijajo določene etične vrednote ter odnos. Učitelji učence ne le podpirajo pri usvajanju znanja, pač pa tudi pri razvoju t. i. mehkih kompetenc, npr. načinov razmišljanja (ustvarjalno mišljenje, kritično mišljenje, reševanje težav, sprejemanje odločitev, samoregulirano učenje), načinov delovanja (komunikacija in sodelovanje), rabi orodij (vključno z informacijsko-komunikacijsko tehnologijo) in kompetenc, ki se povezujejo $z$ državljanstvom, življenjem in s kariero kot tudi z osebno in družbeno odgovornostjo (Golinkoff Michnick in Hirsh-Pasek 2016). Učitelji torej nosijo veliko odgovornost za izobraževanje državljanov 21. stoletja, ki naj bi bili aktivni, iniciativni, samozavestni ter kompetentni tako na kognitivnem, čustvenem, socialnem kot tudi na tehnološkem področju (Bautista in Ortega-Ruiz 2015).

Profesionalni razvoj učiteljev se omenja in opredeljuje $v$ številnih mednarodnih dokumentih (OECD 2005; 2009; 2012) in je bil predmet mnogih študij (Avalos 2011; Huberman in Gronauer 1993; Huberman 1995; Marzano 2003; Terhart 2000; Tsui 2007), kar jasno kaže na njegov pomen in pomembnost. $S$ tematiko so se ukvarjali tudi nekateri slovenski raziskovalci (Čotar Konrad 2015; Čotar Konrad in Rutar 2015; Ivanuš Grmek in Lepičnik Vodopivec 2008; Valenčič Zuljan 2001), ki so se osredotočali na posebnosti v profesionalnem razvoju slovenskih učiteljev. Ugotavljamo pa, da je bil učiteljev profesionalni razvoj v Sloveniji obravnavan skoraj izključno $v$ kontekstu analize njihove 
udeležbe $v$ različnih formalnejših (npr. tečaji, delavnice, konference, seminarji, mreže) in manj formalnih (npr. branje strokovne literature, pogovori s sodelavci) oblikah izobraževanja, manj pozornosti pa je bilo namenjene neformalnemu razvoju, ki se umešča na področje dela s sodelavci, kolegialnih hospitacij, kulturnih in družbenih vrednot, šolske klime ipd. Pričujoča študija se tako ne ukvarja z vprašanjem udeležbe na različnih izobraževanjih, pač pa se usmerja bolj v percepcijo in motivacijo učiteljev za njihov profesionalni razvoj in tako naslavlja tako osebne dejavnike kot tudi dejavnike iz okolja, ki vplivajo na učiteljev profesionalni razvoj.

Študija temelji je na modelu kariernega cikla učiteljev (Burke idr. 1987; Fessler 1992), glavni cilj pa je bil ugotoviti, ali obstajajo razlike v stopnjah kariernega cikla in začetni motivaciji za učiteljski poklic, in sicer glede na učiteljev spol, vrsto formalnega začetnega izobraževanja, delovno dobo, ter ali obstaja povezanost med stopnjami kariernega cikla in motivacijo pri izbiri poklica. Študija je sestavljena iz dveh delov. V teoretičnem delu se osredotočamo na učiteljev profesionalni razvoj v povezavi s stopnjami razvoja, s posebnim poudarkom na modelu kariernega cikla učiteljev (Burke idr. 1987; Fessler 1992). Nato predstavimo nekaj rezultatov podobnih predhodnih študij ter se usmerimo v možne izobraževalne poti, ki vodijo do učiteljskega poklica. V empiričnem delu predstavimo metodologijo študije in rezultate, ki jih pojasnimo v povezavi s postavljenimi cilji.

\section{Profesionalni razvoj učiteljev in faze razvoja}

Profesionalni razvoj učiteljev je kompleksen proces, o čemer pričajo tudi različna razumevanja koncepta oz. različne definicije tega pojava. Nekateri avtorji (Van Driel in Berry 2012) poudarjajo predvsem vidik znanja nekega področja poučevanja, drugi se osredotočajo tako na poznavanje predmetnega področja kot tudi na pedagoške kompetence (Avalos 2011), nekateri modeli pa poudarjajo tudi moralne elemente (Terhart 2000). Različni pogledi rezultirajo tudi v različnih definicijah profesionalnega razvoja učiteljev. Tako Day (1999) trdi, da profesionalni razvoj vključuje vse naravne učne izkušnje ter vse zavestne in načrtovane dejavnosti, ki naj bi neposredno ali posredno koristile posamezniku, skupini ali šoli in prispevajo k kakovosti izobraževanja. Poudarja, da je profesionalni razvoj proces, v katerem učitelji premislijo o svoji vlogi nosilca sprememb tudi v moralnem smislu in v katerem izgrajujejo svoje kompetence. Modeli profesionalnega razvoja vključujejo različne elemente. Liebermanova (1996) je predstavila tridimenzionalni model, ki vključuje: neposredno poučevanje, učenje $v$ šoli, učenje izven šole. Neposredno poučevanje vključuje tečaje in delavnice, učenje $v$ šoli se nanaša na med- 
šolsko učenje, kritično prijateljstvo, mentorstvo in akcijske raziskave, učenje izven šole pa obsega učne mreže, obisk drugih šol, partnerstvo z drugimi ustanovami itd. Kennedyjeva (2005) je predstavila devet modelov profesionalnega razvoja, ki segajo od usposabljanja, osredotočenega na spretnosti, do transformativnega modela, ki je integracija več modelov (npr. akcijske raziskave, mentorstvo, učne skupnosti itd.)

Obstajajo pa nekateri ključni vidiki profesionalnega razvoja učiteljev, ki so skupni večini definicij (Zysberg in Maskit 2017): (i) profesionalni razvoj je dlje časa trajajoči proces pomembnih sprememb, (ii) profesionalni razvoj se dogaja v posamezniku, (iii) spremembe se lahko pojavijo $v$ učiteljevem vsebinskem znanju, pedagoškem znanju, metakognitivnih spretnostih, osebnih ali medosebnih pogledih in spretnostih ter v drugih vidikih, (iv) pričakuje se, da bodo te spremembe vplivale na učiteljevo poučevanje in učenčeve učne izide.

Učiteljev profesionalni razvoj tradicionalno sestavljata dva medsebojno povezana sklopa: začetno izobraževanje učiteljev (ZIU), ki označuje študij za poklic učitelja, in pa stalno strokovno izpopolnjevanje (SSI), ki označuje obdobje od vstopa $v$ učiteljski poklic pa vse do upokojitve.

Obstoječi modeli kariernih ciklov učitelja kažejo na dve skupini modelov (Zysberg in Maskit 2017), in sicer na (i) modele, ki profesionalni razvoj razumejo kot linearen proces, $v$ katerem učitelji konstantno izboljšujejo svoje poklicne kompetence, ter (ii) modele, ki profesionalni razvoj razumejo kot cikličen proces, ki vključuje tako vzpone kot tudi padce (npr. Kagan 1992; Katz 1972; Berliner 1992).

Modeli, ki učiteljevo kariero opisujejo kot linearno napredovanje od stopnje do stopnje, slonijo na razumevanju, da učitelj napreduje med stopnjami brez kritičnega premisleka o prejšnji stopnji, stopnje pa so pogosto vezane na dolžino delovne dobe. Prvi linearni model je razvila Katzeva (1972), ki je želela ugotoviti, kakšna usposabljanja učitelji potrebujejo na določeni stopnji profesionalnega razvoja, in tako identificirala štiri stopnje. Prva stopnja je stopnja preživetja, ki jo označuje tesnoba kot posledica doživljanja razlik med pričakovanji in realnostjo učiteljskega poklica. Druga stopnja je stopnja konsolidacije, ki se začne približno eno leto po stopnji preživetja in v kateri učitelji postanejo samozavestnejši ter se osredotočijo na učence in njihove potrebe. Tretja stopnja je stopnja obnove, ki jo označuje občutek stagnacije in se običajno pojavi v tretjem ali četrtem letu poučevanja. Četrta stopnja je stopnja zrelosti, ki se pojavi po treh ali več letih izkušenj s poučevanjem. Ta model se osredotoča le na prvih nekaj let, je pa bil to prvi model profesionalnega razvoja učiteljev, ki je profesionalni razvoj zastavil kot stopnje, tudi v 
povezavi s terminsko opredelitvijo. Model so nato dopolnjevali različni avtorji (Kagan 1992; Berliner 1992; Huberman 1995). Huberman (1995) ga je razdelil na podstopnje in jih povezal s profesionalnimi aktivnostmi učiteljev - ta kvantificiran model se najpogosteje in zelo široko uporablja v slovenskih študijah o profesionalnem razvoju učiteljev (npr. Čotar Konrad 2015; Ivanuš Grmek in Lepičnik Vodopivec 2008; Javornik Krečič 2008; Valenčič Zuljan 2001).

Za Hubermanov model (1995) velja, da je prva stopnja, ki se povezuje s prvimi tremi leti delovnih izkušenj, vstopna točka kariere, točka preživetja in odkritja. Drugo stopnjo doživljajo učitelji s 4-6-letnimi izkušnjami poučevanja in je označena s profesionalno stabilizacijo. Tretjo stopnjo doživljajo učitelji s 7-18-letnimi delovnimi izkušnjami. Ta stopnja je označena s preizkušanjem dejavnosti in poklicnim eksperimentiranjem, je stopnja poklicnega aktivizma ali pa vstop v stopnjo negotovosti in ponavljajoče se samoevalvacije. Ta dva načina delovanja sta povezana, učitelji pa se lahko premikajo iz enega $v$ drugega. Na četrti stopnji se nahajajo učitelji z 19-30 leti delovnih izkušenj, pri čemer se pojavita konservatizem in jasnost: konservatizem označuje upad poklicnih ambicij, jasnost pa povečane poklicne ambicije. Po tej stopnji lahko učitelji poiščejo nove izzive in postanejo še ambicioznejši, lahko pa se pripravljajo na upokojitev.

Kot smo že navedli, poznamo tudi modele profesionalnega razvoja učiteljev, ki karierni razvoj učiteljev opredeljujejo kot cikličen proces. Eden takšnih modelov je model učiteljevega kariernega razvoja (Burke idr. 1987; Fessler 1992), iz katerega smo izhajali tudi pri naši študiji.

Model kariernega cikla učiteljev (Burke idr. 1987; Fessler 1992) opredeli osem stopenj v kariernem ciklu in poudarja, da te stopnje ne potekajo linearno, pač pa gre za nek smiseln potek dogodkov v učiteljevi karieri. Učitelj gre lahko skozi določeno stopnjo večkrat, lahko pa nekatere tudi preskoči. Opredelitev posameznih stopenj temelji predvsem na učiteljevem odnosu do dela, kar se odraža tako na kognitivnem kot tudi čustvenem področju. Odnos se razlikuje od stopnje do stopnje in se kaže v različnih prednostnih nalogah, težavah in dejavnostih posameznega učitelja. Model tako koncept kariernega cikla pojmuje kot preplet osebnih in okoljskih dejavnikov.

Prvo stopnjo so poimenovali stopnja pred vstopom v poklic; gre za obdobje, ki vključuje začetno izobraževanje za poklic ali pripravo na novo profesionalno vlogo. Druga stopnja, indukcija, označuje prva leta opravljanja učiteljskega poklica, ko se učitelj poskuša prilagoditi vlogi in biti sprejet v svojem poklicnem okolju. Ta stopnja se lahko ponovi ob morebitnih spremembah, kot npr. službi v drugi šoli. Tretja stopnja, krepitev kompetenc, se običajno začne, ko je učitelj že dobro vpet $v$ sistem. Na tej stopnji je učitelj običajno 
zelo motiviran za pridobivanje novega znanja, poskuša izboljšati svoje metode poučevanja, razvijati didaktične spretnosti ter spoznati različna učna gradiva in pripomočke. Na tej stopnji učitelji pogosto kažejo zanimanje za sodelovanje $v$ različnih programih strokovnega izpopolnjevanja. Ta stopnja se šteje za pomembno križišče; tisti, ki uspejo v tej fazi, se premaknejo na naslednjo stopnjo, ki jo označuje rast, drugi pa se lahko srečujejo s karierno frustracijo. Tisti, ki so uspešno izgradili svoje kompetence, nato preidejo na četrto stopnjo, stopnjo navdušenja in rasti. Učitelji na tej stopnji imajo pozitiven odnos do šolskih dejavnosti in razrednega dela ter želijo prispevati h kakovosti šole, v kateri so zaposleni. Obstaja pa možnost razvoja negativnega odnosa do dela pa tudi pojava izgorelosti - to je peta stopnja, karierna frustracija. Ta stopnja se najpogosteje pojavi sredi učiteljeve kariere, vendar jo lahko doživijo tudi začetniki ali učitelji, katerih delovna mesta so negotova. Povezuje se z dejstvom, da se učitelji srečujejo z neznanimi situacijami, nepredvidljivimi okoliščinami in nalogami, za katere se ne čutijo dovolj opolnomočeni. Karierna frustracija je lahko povezana tudi s tem, da se učitelj profesionalno ni dovolj prilagodil, pa tudi z nespodbudnim delovnim okoljem (Fessler 1995). Šesta stopnja, karierna stabilnost, se odlikuje z zmerno predanostjo opravljanju delovnih dejavnosti in včasih tudi s stagnacijo profesionalnega razvoja. Učitelji so sicer predani poučevanju, ampak vanj vlagajo manj truda kot na stopnji navdušenja in rasti. Sedma stopnja je stopnja umirjanja, ki jo označuje priprava na upokojitev, kar nekatere učitelje navdaja z veseljem, druge z žalostjo. Trajanje te stopnje se glede na posameznika bistveno razlikuje, traja lahko več tednov ali več let. Osma stopnja, izstop iz kariere, pa nastopi, ko učitelji zaradi različnih razlogov prenehajo poučevati (npr. zaradi drugega delovnega mesta, iz osebnih ali družinskih razlogov, zaradi upokojitve).

Eros (2011) meni, da je pri obravnavi profesionalnega razvoja po stopnjah potrebno vključiti različne vidike, npr. osebni vidik (npr. družina, selitev) in izobraževalne dejavnike (npr. sprememba stopnje poučevanja ali predmetnega področja, dolžina poučevanja, vključitev v izobraževanje za pridobitev višje stopnje izobrazbe), Ivanuš Grmekova in Lepičnik Vodopivčeva (2008) pa omenjata delitev na notranje (npr. prepričanja učiteljev) in zunanje dejavnike (npr. formalno in neformalno izobraževanje, uvajanje inovacij v vzgojnoizobraževalno prakso idr.). Upoštevati je potrebno tudi izkušnje učiteljev in okoliščine odločitve za učiteljski poklic (Tsui 2007).

Prav dejavniki izbire poklica so bili postavljeni v središče zanimanja številnih raziskav. Huberman in Grounauer (1993) sta razloge za izbiro poklica razdelila v dve skupini: eno predstavljajo materialni dejavniki (varnost zaposlitve, dohodek, dolge počitnice) in drugo profesionalni (ljubezen do pred- 
meta, želja po delu z otroki). Calderhead and Schorrockova (1997) sta ugotovila, da je najpogostejši motiv za izbiro učiteljskega poklica notranje zadovoljstvo, za katerega bodoči učitelji pričakujejo, da ga bodo občutili pri opravljanju službe. Javornik Krečičeva in Ivanuš Grmekova (2005) sta oblikovali pet skupin razlogov za izbiro učiteljskega poklica: (i) samouresničenje (želja po osebni in strokovni rasti ter koristno in vplivno delo), (ii) altruizem (talent in osebni interes), (iii) materialni razlogi (zunanja motivacija, ekonomske in socialne koristi), (iv) aspiracije in stereotipi (tako osebne kot povezane s poklicem); (v) alternativni razlogi (npr. nedostopnost nekega druga študijskega programa). Temeljit pregled literature je pokazal, da doslej še ni bila opravljena študija, ki bi neposredno povezovala motivacijo za vstop v poklic in stopnje profesionalnega razvoja, kaže pa se (Darling-Hammond 2012) pomen začetnega izobraževanja učiteljev pri zadovoljstvu s službo, vztrajanju v njej in rezultatih dela.

V zvezi z vlogo spola je bilo ugotovljeno, da so ženske bolj kot moški predane učiteljskemu poklicu (Ingersoll idr. 1997) ter da po zaključenem začetnem izobraževanju več žensk kot moških izkaže dejansko namero vključitve v učiteljski poklic (Guarino, Santibanez in Daley 2006; Rots, Aelterman in Devos 2014). Študija Teaching Careers in Europe (Eurydice 2018) kaže, da učiteljski poklic bolj velja za ženski poklic. Podobno je bilo ugotovljeno tudi za slovensko situacijo (Tašner, Žveglič Mihelič in Mecin Čeplak 2017).

Raziskave vloge dolžine delovnih izkušenj s poučevanjem so $v$ glavnem izhajale iz razumevanja profesionalnega razvoja $v$ smislu pridobivanja strokovnega znanja, kar kaže na razumevanje profesionalnega razvoja kot strukturiranega strokovnega učenja, ki vključuje aktivnosti, ki naj bi povečale učiteljevo znanje (Darling-Hammod, Hyler in Gardner 2017). Te raziskave kažejo, da učitelji pomemben vpliv na profesionalni razvoj pripisujejo organiziranim izobraževanjem, ki so potekala na šoli, kjer poučujejo (Valenčič Zuljan 2018). Ob tem naj navedemo, da sodelovanje na teh izobraževanjih upada sorazmerno z naraščanjem učiteljeve starosti.

\section{Postati srednješolski učitelj}

Kot je navedeno v poročilu Teaching Careers in Europe (Eurydice 2018), lahko srednješolski učitelji v Evropi pridobijo izobrazbo po običajni poti ali po alternativni poti. Običajna pot pomeni, da bodoči učitelji študirajo na programih začetnega izobraževanja učiteljev, in sicer se lahko odločijo za zaporedni ali sočasni model. Sočasni študijski programi so osredotočeni na izobraževanje učiteljev od začetka in vključujejo tako študij nekega predmetnega področja kot tudi psihološko-pedagoške predmete (npr. pedagogika, didaktika, peda- 
goška psihologija ipd.). Zaporedni model pa označuje pot, po kateri študentje najprej zaključijo nek nepedagoški študijski program in se šele nato odločijo za nadaljevanje študija po pedagoškem programu. Alternativna pot je običajno prilagodljiva, večinoma povezana z zaposlitvijo in krajša od običajnih pedagoških študijskih programov. Ti programi se po Evropi precej razlikujejo.

Tako kot v večini evropskih držav (Eurydice 2013) morajo kandidati za srednješolske učitelje $v$ Sloveniji zaključiti magistrsko raven študija. $V$ skladu $s$ Pravilnikom o usposabljanju učiteljev in drugih strokovnih delavcev v izobraževalnih programih gimnazije (2015) in Pravilnikom o usposabljanju učiteljev in drugih strokovnih delavcev $v$ poklicnem in strokovnem izobraževanju v Sloveniji (2011) sta kandidatom na voljo dve glavni poti, po katerih se lahko učitelji usposobijo za poučevanje v srednješolskem izobraževanju. Bodoči učitelji se lahko vključijo v pedagoške programe; ti sočasni programi se običajno izvajajo na pedagoških fakultetah in nekaterih drugih fakultetah. Študij na teh programih bodočim učiteljem omogoči, da pridobijo specifična predmetna znanja ter kompetence, povezane s poučevanjem, prav tako opravljajo tudi pedagoško prakso. Druga možnost pridobitve ustrezne izobrazbe so zaporedni programi, kar v praksi pomeni, da kandidati za učitelje navadno zaključijo študij po nepedagoškem programu, nato pa se vpišejo na pedagoški magistrski študijski program, ki ga izvajajo različne fakultete. Alternativne poti do ustrezne izobrazbe za učitelja so sicer v Evropi redke (Eurydice 2013), Slovenija pa je ena od devetih evropskih držav, ki poleg tradicionalnega modela začetnega izobraževanja učiteljev ponujajo tudi alternativno pot. Ta alternativna pot se imenuje pedagoško-andragoško izobraževanje (PAI), obsega 60 kreditnih točk in pokriva pedagogiko, splošno didaktiko, predmetnospecifično didaktiko, razvojno in pedagoško psihologijo, pedagoško raziskovanje in pedagoško prakso.

\section{Cilji študije}

Cilj študije je bil ugotoviti, ali obstajajo razlike $v$ stopnjah kariernega cikla in začetni motivaciji za izbiro poklica glede na učiteljeve spol, vrsto formalnega izobraževanja ter dolžino delovnih izkušenj s poučevanjem. Želeli smo tudi ugotoviti, ali obstaja povezanost med stopnjami kariernega cikla in motivacijo pri izbiri poklica.

\section{Metodologija študije}

Uporabili smo deskriptivno in kavzalno-neeksperimentalno metodo empiričnega pedagoškega raziskovanja ter pripravili presečno študijo. 


\section{Vzorec}

V študijo je bilo priložnostno vključenih 94 srednješolskih učiteljev iz Slovenije. Med sodelujočimi je bilo 59 (62,1\%) žensk in 35 (36,8\%) moških. Večina $(63,5 \%)$ vključenih učiteljev je ustrezno izobrazbo pridobila na sočasnih, torej pedagoških študijskih programih, ostali so najprej zaključili nepedagoški študij in ustrezno kvalifikacijo pridobili z vključitvijo v program izpopolnjevanja (pedagoško-andragoško izobraževanje). Večina (55,0 \%) anketirancev ima več kot 21 let delovnih izkušenj s poučevanjem, sledijo (34,9\%) anketiranci z 11-20 leti delovnih izkušenj. Odstotek učiteljev s 6-10 leti ali 5 leti delovnih izkušenj ali manj je bil nizek (8,3 in 1,8\%).

\section{Postopek zbiranja podatkov}

Podatki so bili zbrani s slovensko različico lestvice karierne izbire in lestvice kariernega razvoja (Štemberger in Kukanja Gabrijelčič 2016). Prvi del lestvice sestavlja 14 postavk (cela lestvica $\alpha=0,76$ ), ki merijo ustreznost treh različnih motivacijskih sklopov za poklicno izbiro učiteljev: notranji dejavniki (interes, sposobnosti, osebnostne lastnosti, ljubezen do dela z otroki $(\alpha=0,82))$, dejavniki iz okolja (interesi in vrednote staršev, vpliv učitelja, družinsko ozadje, knjige $(\alpha=0,78)$ ) in zunanji dejavniki (možnost zaposlitve, prihodek, delovni čas, varnost $(\alpha=0,82)$ ). Drugi del lestvice sestavlja 34 postavk (cela lestvica $\alpha=0,70$ ), namenjenih značilnostim šestih stopenj kariernega cikla, od indukcije do kariernega umirjanja (stopnji začetnega izobraževanja in izhoda iz poklica nista bili vključeni). Vprašalnik je vključeval tudi vprašanja, ki se navezujejo na socio-demografske značilnosti (spol, vrsta formalnega izobraževanja za učiteljski poklic (tj. sočasno ali zaporedno), izkušnje s poučevanjem). Veljavnost instrumenta je bila preverjena $z$ uporabo faktorske analize, ki je pokazala, da prvi konstrukt (tj. karierna frustracija) pojasnjuje 26,1\% variance, kar je nad kritično vrednostjo $20 \%$ (Field 2005), in lahko zaključimo, da je instrument veljaven.

\section{Analiza podatkov}

Podatki so bili obdelani z uporabo SPSS. Ker se vrednosti numeričnih spremenljivk niso normalno porazdeljevale, smo za nadaljnje analize uporabili neparametrične preizkuse. Za preverjanje razlik v stopnjah kariernega cikla (indukcija, krepitev kompetenc in navdušenje, karierna frustracija, karierna stabilnost, karierno umirjanje, karierni izhod) in v motivaciji za vstop v poklic (notranja, zunanja, okolje) glede na spol učiteljev in vrsto formalnega izobraževanja je bil uporabljen Mann-Whitneyev preizkus. 
Preglednica 1 Rezultati Mann-Whitneyevega preizkusa za preverjanje razlik v stopnjah kariernega cikla in motivacije za izbiro poklica glede na spol

\begin{tabular}{|c|c|c|c|c|}
\hline \multirow[t]{2}{*}{ Stopnja/motivacija } & \multicolumn{2}{|c|}{ Spol $(\bar{R})$} & \multirow[t]{2}{*}{$U$} & \multirow[t]{2}{*}{$2 P$} \\
\hline & Moški & Ženski & & \\
\hline Indukcija & 60,58 & 40,92 & 644,500 & 0,000 \\
\hline Krepitev kompetenc in navdušenje & 47,29 & 49,23 & 1036,500 & 0,740 \\
\hline Frustracija & 49,27 & 47,26 & 1005,500 & 0,730 \\
\hline Stabilnost & 46,71 & 47,17 & 1005,000 & 0,929 \\
\hline Umirjanje & 53,61 & 44,73 & 853,500 & 0,116 \\
\hline Izhod & 49,64 & 46,23 & 957,500 & 0,521 \\
\hline Notranja & 42,47 & 54,69 & 873,000 & 0,035 \\
\hline Zunanja & 53,51 & 46,96 & 987,500 & 0,264 \\
\hline Okoljska & 55,82 & 44,61 & 862,000 & 0,053 \\
\hline
\end{tabular}

Opombe $\bar{R}$ - povprečni rang, $U$ - Mann-Whitneyev preizkus, $2 P$ - statistična pomembnost.

Za preverjanje razlik v stopnjah kariernega cikla in motivacije za izbiro učiteljskega poklica glede izkušnje s poučevanjem pa je bil uporabljen KruskalWallisov preizkus. Za preverjanje povezanosti med stopnjami kariernega cikla in različnimi načini motivacije smo uporabili Pearsonov korelacijski koeficient.

\section{Rezultati}

Rezultati so predstavljeni na osnovi ciljev študije:

- ugotoviti, ali obstajajo razlike $v$ stopnjah kariernega cikla in začetni motivaciji za izbiro učiteljskega poklica glede na spol ter glede na delovne izkušnje s poučevanjem;

- ugotoviti, ali obstaja povezanost med stopnjami kariernega cikla in motivacijo pri izbiri poklica.

\section{Razlike $v$ stopnjah poklicnega cikla in začetni motivaciji}

Rezultati Mann-Whitneyevih preizkusov kažejo, da glede na spol med učitelji obstajajo statistično pomembne razlike $v$ fazi indukcije ter $v$ notranji motivaciji za izbiro poklica. Kot lahko razberemo iz preglednice 1 , učitelji statistično višje $\left(R^{2}=60,58\right)$ ocenjujejo fazo indukcije kot učiteljice $\left(R^{2}=40,92\right)$. Rezultati kažejo, da učitelji moškega spola vlagajo več truda $v$ to, da bi se poskušali vklopiti v šolo, da bi jih kolegi sprejeli in da bi bili uspešni pri poučevanju. Druga statistično pomembna razlika $(U=873.000,2 P=0,035)$ je bila ugotovljena pri razlikah v notranji motivaciji za izbiro učiteljskega poklica. V primer- 
Preglednica 2 Rezultati Kruskal-Wallisovega preizkusa za ugotavljanje razlik v stopnjah kariernega cikla in motivacije za izbiro poklica glede na izkušnje s poučevanjem

\begin{tabular}{|c|c|c|c|c|c|c|}
\hline \multirow[t]{2}{*}{ Stopnja/motivacija } & \multicolumn{4}{|c|}{ Leta izkušenj $(\bar{R})$} & \multirow[t]{2}{*}{$H$} & \multirow[t]{2}{*}{$P$} \\
\hline & $\leq 5$ & $6-10$ & $11-20$ & $\geq 21$ & & \\
\hline Indukcija & 38,50 & 38,81 & 48,67 & 50,24 & 1,457 & 0,692 \\
\hline Krepitev in navdušenje & 29,00 & 6231 & 48,09 & 47,06 & 3,264 & 0,234 \\
\hline Frustracija & 74,50 & 48,81 & 44,68 & 49,44 & 2,651 & 0,449 \\
\hline Stabilnost & 60,50 & 51,71 & 46,94 & 46,14 & 1,575 & 0,665 \\
\hline Umirjanje & 22,50 & 38,31 & 36,85 & 56,89 & 0,647 & 0,886 \\
\hline Izhod & 29,50 & 43,57 & 44,77 & 50,11 & 13,699 & 0,003 \\
\hline Notranja & 31,00 & 42,38 & 55,04 & 48,44 & 1,858 & 0,602 \\
\hline Zunanja & 80,00 & 63,31 & 50,17 & 46,75 & 4,617 & 0,202 \\
\hline Okoljska & 55,50 & 47,50 & 45,56 & 52,31 & 1,355 & 0,716 \\
\hline
\end{tabular}

Opombe $\bar{R}$-povprečni rang, $H$ - Kruskal-Wallisov preizkus, $P$-statistična pomembnost.

Preglednica 3 Rezultati Mann-Whitneyevega preizkusa za preverjanje razlik v stopnjah poklicnega cikla in motivacije za izbiro učiteljskega poklica glede na vrsto začetnega formalnega izobraževanja

\begin{tabular}{|c|c|c|c|c|}
\hline \multirow[t]{2}{*}{ Stopnja/motivacija } & \multicolumn{2}{|c|}{ Izobraževanje $(\bar{R})$} & \multirow[t]{2}{*}{$U$} & \multirow[t]{2}{*}{$2 P$} \\
\hline & Sočasno & Zapored. & & \\
\hline Indukcija & 42,25 & 44,37 & 784,000 & 0,704 \\
\hline Krepitev kompetenc in navdušenje & 41,81 & 46,65 & 745,500 & 0,388 \\
\hline Frustracija & 41,74 & 45,43 & 741,500 & 0,510 \\
\hline Stabilnost & 40,77 & 44,41 & 702,500 & 0,449 \\
\hline Umirjanje & 41,79 & 45,37 & 744,000 & 0,511 \\
\hline Izhod & 41,38 & 44,73 & 721,500 & 0,511 \\
\hline Notranja & 50,60 & 32,70 & 516,000 & 0,001 \\
\hline Zunanja & 40,28 & 51,07 & 643,000 & 0,057 \\
\hline Okoljska & 44,73 & 41,20 & 771,000 & 0,528 \\
\hline
\end{tabular}

Opombe $\bar{R}$-povprečni rang, $U$ - Mann-Whitneyev preizkus, $2 P$ - statistična pomembnost.

javi z učitelji $\left(R^{2}=42,47\right)$ so učiteljice $\left(R^{2}=54,69\right)$ bolj notranje motivirane za izbiro učiteljskega poklica, kar pomeni, da so ga izbrale zaradi svojih interesov, osebnosti in ljubezni do dela z otroki. Poleg tega $v$ primeru okoljske motivacije za izbiro poklica obstaja tendenca $(U=862.000,2 P=0,053)$, da so moški učitelji pri izbiri poklica bolj pod vplivom dejavnikov iz okolja, torej interesov svojih staršev, družinskih vrednot, družinskega ozadja itd.

Kot je prikazano v preglednici 2, so bile statistično pomembne razlike glede na delovno dobo ugotovljene na stopnji izhoda $(H=13,699, P=0,003)$. Kot 
Preglednica 4 Povezanost med stopnjami kariernega cikla in motivacijo za izbiro učiteljskega poklica

\begin{tabular}{lrrrrrrrrr}
\hline Stopnja/motivacija & 1 & 2 & 3 & 4 & 5 & 6 & 7 & 8 & 9 \\
\hline 1 Indukcija & 1,000 & - & & & & & & & \\
2 Krepitev* & $-0,016$ & 1 & & & & & & \\
3 Frustracija & $0,480^{* *}$ & 0,150 & 1 & & & & & & \\
4 Stabilnost & 0,028 & 0,120 & 0,282 & 1 & & & & & \\
5 Umirjanje & 0,128 & 0,125 & $0,421^{* *}$ & 0,163 & 1 & & & & \\
6 Izstop & 0,121 & 0,060 & $0,385^{* *}$ & 0,228 & $0,327^{* *}$ & 1 & & & \\
7 Notranja & $-0,129$ & 0,032 & $-0,111$ & $-0,112$ & $-0,118$ & 0,068 & 1 & & \\
8 Zunanja & 0,155 & 0,093 & 0,080 & 0,048 & 0,196 & 0,114 & 0,159 & 1 & \\
9 Okoljska & 0,068 & 0,150 & 0,110 & 0,169 & 0,086 & 0,091 & 0,013 & 0,004 & 1 \\
\hline
\end{tabular}

Opombe ${ }^{*}$ Kompetenc in navdušenje. ${ }^{*}$ Korelacija je statistično pomembna na ravni 0,05 .

je bilo pričakovati, je bila najvišja ocena $\left(R^{2}=56,89\right)$ ugotovljena za skupino učiteljev $z 21$ leti delovnih izkušenj pri poučevanju ali več. Vse druge skupine so to fazo ocenjevale bistveno nižje.

Rezultati Mann-Whitneyevega preizkusa $(U=516,000,2 P=0,001)$ kažejo, da obstajajo statistično pomembne razlike $v$ notranji motivaciji za izbiro poklica glede na vrsto začetnega izobraževanja. Jasno je, da učitelji, ki se odločijo za študij na pedagoških programih (torej so se na začetku študija odločili za učiteljski poklic), izkazujejo višjo stopnjo $\left(R^{2}=50,60\right)$ notranje motivacije kot učitelji, ki so sprva končali nepedagoški študij in se za pedagoško dokvalifikacijo odločili kasneje $\left(R^{2}=32,70\right)$. Poleg tega obstaja tendenca $(U=$ $643,000,2 P=0,057)$, da so učitelji, ki se za učiteljski poklic odločijo kasneje, bolj zunanje motivirani.

\section{Povezanost med stopnjami kariernega cikla in motivacijo pri izbiri poklica}

Rezultati kažejo, da je prva stopnja, indukcija, pozitivno in statistično pomembno povezana s frustracijo $(r=0,480)$. $V$ fazi indukcije se učitelji poskušajo povezati s sodelavci, šolo in z učenci, $v$ fazi frustracije pa so učitelji razočarani nad poklicem in znova poskušajo najti svoje mesto, s pogostimi mislimi o iskanju službenih položajev izven šole.

Stopnja frustracije je pozitivno in statistično značilno povezana $s$ stopnjama umirjanja $(r=0,421)$ in izstopa $(r=0,385)$, stopnja umirjanja je povezana s stopnjo izstopa $(r=0,327)$, kar kaže, da učitelji, ki so na delovnem mestu frustrirani, razmišljajo o izhodu iz poklica (ali o odhodu v pokoj), skušajo delati čim manj oz. se več ne trudijo. 


\section{Razprava}

Rezultati kažejo, da so učiteljice v primerjavi z učitelji poročale o višji stopnji notranje motivacije pri izbiri poklica. Učiteljice so se za učiteljski poklic odločile predvsem zaradi zanimanja za predmetno področje, na katerem zdaj poučujejo, zaradi svojih osebnih interesov in ker so želele delati z otroki. Učitelji so učiteljski poklic izbrali predvsem zaradi okoljskih dejavnikov, kot je vpliv njihove družine in staršev. Pomembnost mnenja "pomembnih drugih" se kaže tudi v rezultatih v zvezi s stopnjo indukcije; učitelji v primerjavi z učiteljicami več napora vlagajo $v$ prilagajanje učiteljskemu poklicu in sprejetosti v okolju, to je med učenci, starši in sodelavci.

Rezultati tako potrjujejo izsledke predhodnih študij, ki kažejo, da je zavezanost učiteljskemu poklicu višja med učiteljicami (Ingersoll idr. 1997) in da več žensk kot moških izkazuje namero, da po zaključenem študiju dejansko vstopi v učiteljski poklic (Guarino, Santibanez in Daley 2006; Rots, Aelterman in Devos 2014). To težnjo bi morda lahko pripisali še vedno obstoječim stereotipom, povezanim z moškimi in ženskimi poklici (Tašner idr. 2017).

$\checkmark$ zvezi z vprašanjem razlik $v$ stopnjah profesionalnega razvoja in začetne motivacije za izbiro poklica glede na dolžino delovnih izkušenj s poučevanjem rezultati kažejo, da med učitelji obstajajo razlike $v$ stopnji izstopa, pri tem pa se izkaže, da se značilnosti te stopnje povečujejo $z$ leti delovnih izkušenj s poučevanjem in so najopaznejše pri učiteljih, ki imajo s poučevanjem 21 let delovnih izkušenj ali več. Ti v večji meri razmišljajo o izstopu iz poklica in iskanju druge službe.

Rezultati, ki se navezujejo na razlike med učitelji glede na vrsto začetnega izobraževanja, kažejo, da so učitelji, ki so zaključili sočasne izobraževalne programe, izrazili višjo stopnjo notranje motivacije za vstop v učiteljski poklic v primerjavi z učitelji, ki so kvalifikacijo pridobili po zaporednih programih. Rezultati so precej pričakovani, saj so se učitelji, ki so zaključili sočasne programe, odločili postati učitelji že pred samim vstopom, medtem ko so učitelji, ki so študirali po zaporednih programih, to odločitev sprejeli kasneje. Ti rezultati so v skladu z drugimi študijami (npr. Bruinsma in Jansen 2010; Guarino, Santibanez in Daley 2006), ki so pokazale, da se za študij na pedagoških študijskih programih odločajo kandidati, ki so za to delo notranje motivirani.

Ko gre za drugi cilj študije, rezultati kažejo, da je stopnja frustracije pozitivno povezana s stopnjo indukcije, stopnja umirjanja pa je pozitivno povezana s stopnjo izhoda. Navedene štiri stopnje nakazujejo stisko učiteljev v procesu profesionalnega razvoja, tako na samem začetku, proti koncu in tudi vas čas trajanja poučevanja. 
Čeprav v Sloveniji v primerjavi z ostalimi evropskimi državami (Eurydice 2018) ključne težave, povezane $s$ pedagoškim poklicem (npr. pomanjkanje učiteljev in kandidatov za učitelje), niso bili zaznane tako izrazito, rezultati študije kažejo nekatera kritična vprašanja v učiteljski stroki, ki jih je mogoče uporabiti v nacionalnem in mednarodnem kontekstu. Tako, denimo, rezultati o začetni motivaciji za vstop $v$ učiteljski poklic kažejo, da je treba ponovno preučiti vprašanje, kako doseči, da bo poklic učitelja razumljen kot privlačna poklicna izbira, s posebnim poudarkom na privabljanju ljudi v poklic kot prvo poklicno izbiro in privabljanju slabše zastopanih skupin (kot je opredeljeno v OECD 2005), v našem primeru učitelje moškega spola. To vprašanje bi bilo treba obravnavati na treh ravneh: na ravni šol, na ravni fakultet, ki izobražujejo bodoče učitelje, ter na ravni oblikovalcev politike. Ti trije deležniki bi morali skupno vlagati v krepitev statusa učiteljskega poklica. Šole (npr. ravnatelji in učitelji) bi morale graditi močno sodelovanje z lokalno skupnostjo, s starši in z delodajalci. Fakultete, ki izobražujejo bodoče učitelje, bi morale zagotavljati visokokakovostne študijske programe in tesno sodelovati z oblikovalci politik ter $v$ razvoj in izvajanje teh programov vključevati tudi učitelje. Oblikovalci politik bi morali preučiti možnosti za izboljšanje podobe in statusa učiteljev ter izboljšanje delovnih pogojev in plač.

Na osnovi rezultatov ugotavljamo: (i) da se značilnosti stopnje izstopa (razmišljanje o zapustitvi delovnega mesta, menjavi službe) stopnjujejo s povečevanjem delovnih izkušenj s poučevanjem in se najmočneje izražajo pri učiteljih z 21 leti delovne dobe in več ter (ii) da se značilnosti faze frustracije povezujejo tako z značilnostmi faze indukcije kot faze umirjanja ter faze izhoda. Splošna ugotovitev študije je tako, da srednješolski učitelji v Sloveniji izražajo vrsto obdobij stiske skozi celotno poklicno kariero, z najvišjo intenzivnostjo na začetku in ob koncu svoje učiteljske kariere. To poudarja potrebo po vzpostavitvi sistema stalne strokovne podpore, od stopnje indukcije ali celo od samega izobraževanja za učiteljski poklic do upokojitve. Na ravni posameznih šol je treba zagotoviti podporo v obliki sistematičnega vodenja (npr. učiteljev mentorjev) za učitelje začetnike in nadaljevati s kariernim vodenjem pri vodenju ter načrtovanju kariere (npr. prevzemanje novih odgovornosti, izboljšanje ravni kvalifikacij). Poleg tega bi morale vodstvene skupine $v$ posameznih šolah ponovno preučiti svojo vlogo pri zagotavljanju podporne šolske klime, oblikovanju učnih skupnosti in prepoznavanju pomena posameznih učiteljev.

Učitelji na nacionalni ravni bi morali biti dejavno vključeni v različne projekte, kot sta razvoj in izvajanje inovativnih praks in politik. Uvesti bi bilo potrebno sistem za spremljanje prakse $v$ razredu in prepoznavanje dela učite- 
ljev za izboljšanje kakovosti dela in nagraditi učitelje z možnostmi za hitrejše napredovanje, nadaljnji študij in višje plače.

\section{Sklep}

Glavni cilj prispevka je bil ugotoviti, ali obstajajo razlike v stopnjah poklicnega cikla in začetni motivaciji za izbiro poklica glede na učiteljeve spol, vrsto začetnega izobraževanja ter dolžino delovnih izkušenj s poučevanjem. Drugi cilj je bil ugotoviti, ali obstaja povezanost med stopnjami kariernega cikla in motivacijo pri izbiri poklica.

Kar zadeva vlogo spola pri kariernem ciklu in motivaciji, rezultati kažejo, da v primerjavi z učiteljicami učitelji poročajo, da vlagajo več truda, da bi se prilagodili situaciji v šoli in tamkajšnji učiteljski skupnosti. Učiteljice so pokazale višjo stopnjo notranje motivacije pri izbiri učiteljskega poklica, za poklic so se $v$ večji meri odločile zaradi lastnih interesov, ljubezni do dela z otroki in svojih osebnostnih lastnosti. Glede dolžine delovne dobe se je pričakovano izkazalo, da obstajajo razlike na stopnji izstopa. Značilnosti te faze so najvišje ocenili učitelji z 21 ali več leti delovnih izkušenj s poučevanjem, kar nakazuje na potrebo po zagotavljanju stalne podpore učiteljem in po razmisleku o možnostih vključevanja izkušenejših učiteljev v dejavnosti, ki bi jih dodatno motivirale, z namenom, da bi optimalno opravljali svoj poklic. Druga pomembna ugotovitev je bila, da učitelji, ki so se odločili za sočasni študijski program, izkazujejo višjo notranjo motivacijo za poklic. Ugotovili smo tudi, da je stopnja indukcije pozitivno in statistično pomembno povezana s stopnjo frustracije, stopnja frustracije je pozitivno in pomembno povezana s stopnjo umirjanja ter s stopnjo izstopa, stopnja umirjanja pa je pozitivno povezana s stopnjo izhoda.

Na splošno ugotovitve razkrivajo vlogo spola in vrste izobraževanja pri začetni motivaciji za izbiro učiteljskega poklica. Za učiteljice in za tiste, ki so se odločili, da bodo postali učitelji že ob začetku študija, velja, da izkazujejo višjo stopnjo notranje motivacije. Rezultati poudarjajo tudi, da srednješolski učitelji v Sloveniji skozi celotno poklicno kariero doživijo več obdobij stiske, z najvišjo intenzivnostjo na začetku in ob koncu učiteljske kariere. To poudarja potrebo po postavitvi sistema stalne strokovne podpore od samega začetka poučevanja do upokojitve.

\section{Omejitve študije in izhodišča za nadaljnje raziskovanje}

Posploševanje rezultatov študije je zaradi razmeroma majhnega vzorca omejeno, tako da bi bilo študijo smiselno ponoviti na večjem vzorcu. Vendar pa rezultati kažejo na nekaj nevralgičnih točk, ki bi jim bilo potrebno v okviru preu- 
čevanja profesionalnega razvoja nameniti več pozornosti. Opraviti bi bilo potrebno poglobljene raziskave o učiteljih začetnikih in o najizkušenejših učiteljih ( $v$ smislu let delovnih izkušenj) s poudarkom na njihovih prepričanjih, motivaciji in izkušnjah. Takšne raziskave so lahko podlaga za razvoj sistematične strokovne podpore za učitelje. Raziskava bi bila lahko usmerjena tudi v raziskovanje sedanjih podpornih sistemov, tudi v smislu učečih se skupnosti.

\section{Literatura}

Avalos, B. 2011. »Teacher Professional Development in Teaching and Teacher Education over Ten Years." Teaching and Teacher Education 27 (1): 10-20.

Bautista, A., in R. Ortega-Ruíz. 2015. »Teacher Professional Development: International Perspectives and Approaches. «Psychology, Society and Education 7 (3): 240-251.

Bell, B., in J. Gilbert. 1994. »Teacher Development as Professional, Personal, and Social Development." Teaching and Teacher Education 10 (5): 483-497.

Berliner, D. C. 1992. „The Nature of Expertise in Teaching."V Effective and Responsible Teaching: The New Synthetises, ur. F. Oser, A. Dick in J. L. Patry, 227-249. San Francisco, CA: Josey-Bass.

Brookfield, S. 2005. Power of Critical Theory for Adult Learning and Teaching. Maidenhead: McGraw-Hill Education.

Bruinsma, M., in E. Jansen. 2010. »/s the Motivation to Become a Teacher Related to Pre-Service Teachers' Intentions to Remain in the Profession?« European Journal of Teacher Education 33 (2): 185-200.

Burke, P. J., J. C. Christensen, R. Fessler, J. H. Mcdonnell in J. R. Price. 1987. »The Teacher Career Cycle: Model Development and Research Report. «Prispevek predstavljen na Annual Meeting of the American Educational Research Association, Washington, DC, 20.-24. april.

Calderhead, J., in S. B. Shorrok. 1997. Understanding Teacher Education. London: Falmer.

Čotar Konrad, S. 2015. „Validacija nove lestvice profesionalnega razvoja pedagoškega delavca.«Pedagoška obzorja 30 (3-4): 118-135.

Čotar Konrad, S., in S. Rutar. 2015. »Refleksija: pot do profesionalne identitete in pomemben vir spoznanj o samozaznavi študentov predšolske vzgoje in njihovih mentorjev v javnih vrtcih. «V Aktivnosti učencev $v$ učnem procesu, ur. D. Hozjan, 75-87. Koper: Annales.

Darling-Hammond, L. 2012. Powerful Teacher Education: Lessons from Exemplary Programs. San Francisco, CA: Wiley.

Darling-Hammond, L., M. E. Hyler in M. Gardner. 2017. Effective Teacher Professional Development. Palo Alto, CA: Learning Policy Institute.

Day, C. 1999. Developing Teachers, The Challenges of Lifelong Learning. London: Falmer.

Eros, J. 2011. »The Career Cycle and the Second Stage of Teaching: Implications 
for Policy and Professional Development.« Arts Education Policy Review 112 (2): 65-70.

Eurydice. 2013. Key Data on Teachers and School Leaders in Europe. Bruselj: European Commission.

- 2018. Teaching Careers in Europe: Access, Progression and Support. Luksemburg: Publications Office of the European Union.

Evans, L. 2002. »What is Teacher Development?« Oxford Review of Education 28 (1): 123-137.

Fessler, R. 1992. »The Teacher Career Cycle.« V The Teacher Career Cycle, ur. R. Fessler in J. C. Christensen, 21-44. Boston, MA: Allyn and Bacon.

_ . 1995. »Dynamic of Teacher Career Stages.«V Professional Development in Education, New Paradigms and Practices, ur. T. Guskey in M. Huberman, 171-192. New York: Teachers College.

Field, A. 2005. Discovering Statistics Using SPSS. London: Sage.

Golinkoff, R. M., in K. Hirsh-Pasek, K. 2016. Becoming Brilliant: What Science Tells Us about Raising Successful Children. Washington, DC: American Psychological Association.

Goodson, I. 2003. Professional Knowledge, Professional Lives: Studies in Education and Change. Philadelphia, PA: Open University Press.

Guarino, C. M., L. Santibanez in G. A. Daley. 2006. »Teacher Recruitment and Retention. "Review of Educational Research 76 (2): 173-208.

Huberman, M. 1995. The Lives of Teachers. New York: Teachers College Press; London: Cassell.

Huberman, M., in M. M. Gronauer. 1993. »Teachers' Motivations and Satisfactions." V M. Huberman M., M. M. Grounauer in J. Marti, The Lives of Teachers, 86-101. New York: Teachers College Press; London: Cassell.

Ingersoll, R. M., R. M. I. N. A. Peggy, Q. S. Bobbitt, N. Alsalam, P. Quinn in S. Bobbitt. 1997. Teacher Professionalization and Teacher Commitment: A Multilevel Analysis. Washington, DC: National Centre for Education Statistics.

Ivanuš Grmek, M., in J. Lepičnik Vodopivec. 2008. »Profesionalni razvoj učitelja razredne nastave. «V Pedagogy and the Knowledge Society: Collected Papers of the 2nd Scientific Research Symposium Pedagogy and the Knowledge Society, ur. M. Cindrič, V. Domović in M. Matijević, 113-120. Zagreb: Učiteljski fakultet.

Javornik Krečič, M. 2008. Pomen učiteljevega profesionalnega razvoja za pouk. Ljubljana: i2.

Javornik Krečič, M., in M. Ivanuš Grmek. 2005. »The Reasons Students Choose Teaching Professions. "Educational Studies 31 (3): 73-81.

Kagan, D. D. 1992. »Professional Growth among Preservice and Beginning Teachers." American Educational Research Journal 62 (2): 129-169.

Katz, L. G. 1972. »Developmental Stages of Preschool Teachers. «The Elementary School Journal 73 (1): 50-54. 
Keiny, S. 1994. »Constructivism and Teachers' Professional Development.« Teaching and Teacher Education 10 (2): 157-167.

Kennedy, A. 2005. »Models of Continuing Professional Development: A Framework for Analysis. " Journal of In-Service Education 32 (2): 235-250.

Lieberman, A. 1996. »Practices that Support Teacher Development: Transforming Conceptions of Professional Learning. « V Teacher Learning: New Policies, New Practices, ur. M. W. McLaughlin in I. Oberman, 185-201. New York: Teachers College Press.

Marzano, R. J. 2003. What Works in School: Translating Research into Action. Alexandria, VA: Association for Supervision and Curriculum Development.

Ministrstvo za šolstvo in šport. 2011. Bela knjiga o vzgoji in izobraževanju v Republiki Sloveniji. Ur. J. Krek in Metljak. Ljubljana: Ministrstvo za šolstvo in šport.

Ministrstvo za šolstvo, znanost in šport. 2001. Zelena knjiga o izobraževanju učiteljev v Evropi: kakovostno izobraževanje učiteljev za kakovost v vzgoji, izobraževanju in usposabljanju; tematsko omrežje o izobraževanju učiteljev $v$ Evropi. Prev. V. M. Borec. Ljubljana: Ministrstvo za šolstvo in šport.

OECD. 2005. Teachers Matter: Attracting, Developing, and Retaining Effective Teachers. Pariz: OECD.

- 2009. Creating Effective Teaching and Learning Environments: First Results from TALIS. Pariz: OECD.

- 2012. Preparing Teachers and Developing School Leaders for 21st Century: Lessons from around the World. Background Report for the International Summit on the Teaching Profession. Pariz: OECD.

Persson, M. 2006. A Vision of European Teaching and Learning: Perspectives on the New Role of the Teacher. Karlstad: Learning Teacher Network.

Pravilnik o izobrazbi učiteljev in drugih strokovnih delavcev v izobraževalnih programih gimnazije. 2015. Uradni list Republike Slovenije, št. 75. https:// www.uradni-list.si/1/objava.jsp?sop=2015-01-2929.

Pravilnik o izobrazbi učiteljev in drugih strokovnih delavcev $v$ poklicnem in strokovnem izobraževanju. 2011. Uradni list Republike Slovenije, št. 48. https://www.uradni-list.si/1/objava.jsp?sop=2011-01-2291.

Rots, I., A. Aelterman in G. Devos. 2014. „Teacher Education Graduates' Choice (Not) to Enter the Teaching Profession: Does Teacher Education Matter?« European Journal of Teacher Education 37 (3): 279-294.

Štemberger, T., in M. Kukanja-Gabrijelčič. 2016. „Validacija slovenske različice Lestvice profesionalnega razvoja učiteljev. «V Sučasni perspektyvy osvity, ur. S. Omelčenko in J. Aksman, 179-191. Horlivka: Institute for Foreign Languages.

Tašner, V., M. Žveglič Mihelic in M. Mencin Ceplak. 2017. »Gender in the Teaching Profession: University Students' Views of Teaching as a Career.« CEPS Journal 7 (2): 47-69. 
Terhart, E. 2000. Conflicting Concepts of Modernization in Teacher Education: Teacher Education Policies in Germany. Predstavitev na Conference on Teacher Education Policies in the European Union and the Quality of Lifelong Learning, Portugalska, 22.-23. maj.

Tsui, A. B. M. 2007. „What Shapes Teachers' Professional Development?« V International Handbook of English Language Teaching, ur. J. Cummings in C. Davison, 1053-1066. Boston, MA: Springer.

Valenčič Zuljan, M. 2001. »Modeli in načela učiteljevega profesionalnega razvoja.«Sodobna pedagogika 52 (2): 122-142.

—. 2018. »Factors of Teachers' Professional Development.« V Reaching Horizons in Contemporary Education, ur. N. Tatković, F. Šuran in M. Diković, 926. Pulj: Juraj Dobrila University of Pula, Faculty of Educational Sciences.

Van Driel, J. H., in A. Berry. 2012. »Teacher Professional Development Focusing on Pedagogical Content Knowledge.« Educational Researcher 41 (1): 26-28.

Villegas-Reimers, E. 2003. Teacher Professional Development: An International Review of the Literature. Pariz: UNESCO.

Zysberg, L., in D. Maskit. 2017. „Teachers' Professional Development, Emotional Experiences and Burnout." Journal of Advances in Education Research 2 (4): 287-300.

\section{The Teacher Career Cycle and Initial Motivation from the Secondary School Teachers' Perspective}

This paper focuses on the career cycle and initial motivation of secondary school teachers in Slovenia and is based on the Teacher Career Cycle Model. The aim of the study was to determine whether there are differences in the career stages and motivation in terms of teachers' gender, mode of formal education and length of work experience in teaching and whether there are any correlations between the stages and motivation. The study included $94 \mathrm{sec}-$ ondary school teachers who completed the Slovenian version of the Career Choice Scale and Career Development Scale. The results show that compared to male teachers, female teachers are more intrinsically motivated in choosing the profession, while male teachers are more insecure in the profession and try to connect with colleagues and pupils. Teachers who completed concurrent programmes show a higher level of intrinsic motivation for the teaching profession. Regarding the role of the length of work experience in teaching, a major wind-down was apparent for teachers with 21 years or more of work experience in teaching. Furthermore, the most correlations were established among the stages of frustration, exit and wind down.

Keywords: teacher, career stages, initial motivation 